\title{
RUSSIA'S IMPACT ON THE COMPETITIVENESS OF OTHER EAEU MEMBER STATES WITH RESPECT TO TRADE IN HIGH-TECH GOODS \\ Krzysztof Falkowski ${ }^{1}$
}

\begin{abstract}
The main objective of this article is to determine the influence of Russia (in terms of their exports to Russia) on the competitiveness of Armenia, Belarus, Kazakhstan and Kyrgyzstan in the international trade of high-tech goods in 2000-2016 in the context of the overall competitiveness of these countries in the international trade in this goods category. To this end, the author's formula was used, which is a modification of the method of analysis of revealed comparative advantages in foreign trade of a given country developed by B. Balassa, while taking into account a hypothetical situation of total exclusion of exports to a country whose impact on the competitiveness of a given country is under examination. The analysis clearly shows that the influence of Russia (in terms of their exports to Russia) on the international competitiveness of Armenia, Belarus, Kazakhstan and Kyrgyzstan in the area of high-tech goods trade in 2000-2016 was generally positive, although it differed in terms of strength of the impact, with the strongest being the case of Belarus and the weakest being the case of Armenia. However, this did not change the overall uncompetitive position of the analysed EAEU countries in the total international trade of high-tech goods.
\end{abstract}

JEL Classification Numbers: F14, O31, P45; DOI: http://dx.doi.org/10.12955/cbup.v6.1140

Keywords: competitiveness, high-tech goods, international trade, Russia, EAEU member states

\section{Introduction}

Nowadays, in the conditions of the intensification of globalisation processes accompanied by the internationalisation of economic activity, popularisation of the phenomenon of coopetition, or the acceleration of the ICT revolution, which leads to a progressive divergence of development between highly and underdeveloped countries, more and more attention is paid to research on the international competitiveness of economies. An important dimension of this competitiveness, especially important in the modern world economy, in the era of increasingly fierce international competition based more and more on knowledge, modern technologies and innovations, is the competitiveness in the field of goods with the highest level of technological advancement.

This article fits directly into this trend of economic research and its main objective is to 1) determine the influence of Russia (in terms of their exports to Russia) on the existing competitiveness of Armenia, Belarus, Kazakhstan and Kyrgyzstan in international trade in high-tech goods in 2000-2016, 2) determine the extent to which Russia's influence translated into the overall competitiveness of the other economies of the Eurasian Economic Union (EAEU) in international high-tech trade. To achieve objective 1, the author's formula was used, which is a modification of the analysis of revealed comparative advantages in foreign trade of a given country developed by B. Balassa, while taking into account a hypothetical situation of total exclusion of exports to a country whose impact on the competitiveness of a given country is under examination. This analysis was additionally preceded by a discussion of the significance of Russia in total export and the export of high-tech goods of this group of countries. In order to achieve objective 2, the logarithmic original formula of Balassa's methodology was used.

This article presents a thesis according to which the influence of Russia (in terms of their exports to Russia) on the international competitiveness of other member states of the EAEU, i.e. Armenia, Belarus, Kazakhstan and Kyrgyzstan, in the scope of trade in high-tech goods in the period of 20002016 was generally positive, although it differed in terms of impact strength, with the strongest being the case of Belarus and the weakest being Armenia. However, this did not change the overall uncompetitive position of the analysed EAEU countries in the international trade of high-tech goods.

\section{Literature review}

Since the formal establishment of the Eurasian Economic Union (EAEU) in early 2015, it has become a fairly popular subject for economic research. In particular, this study focuses on the economic consequences of forming the EAEU and on the effects of this on the economies of the individual countries that make it up (e.g. Vinokurov, 2017; Knobel, 2017). However, there is also no shortage of research on the competitiveness of EAEU countries in contemporary international trade. For example, a detailed analysis of the competitiveness of individual EAEU countries was carried out, inter alia, by

\footnotetext{
${ }^{1}$ World Economy Research Institute, Warsaw School of Economics, Al. Niepodległości 162, 02-554 Warsaw, Poland, kfalkow@sgh.waw.pl
} 
Falkowski (2017b), Hartwell (2016), and Ustyuzhanina (2016). According to Falkowski (2017b), the EAEU member countries are characterised by a diversified, albeit generally low, level of international competitiveness in international trade, while the relatively few comparative advantages held by these countries relate de facto only to medium-low and low technology goods, based mainly on the natural resources they possess. Thus, none of the EAEU member countries has any comparative advantage in the trade of high technology (high-tech) goods.

On the other hand, according to Hartwell (2016), who also proved low competitiveness of EAEU countries on the international arena, emphasizing a particularly destructive role from the point of view of competitiveness, which is played by the existing barriers to innovation of their economies. Nevertheless, as Ustyuzhanina stresses (2016), the elimination of these innovative bottlenecks in the competitiveness of EAEU economies, combined with the use of potential synergy effects resulting from the integration of economies forming the EAEU, creates opportunities to build new internationally competitive value chains in industries not only based on existing raw materials. The low level of innovativeness of individual EAEU member states, which is directly reflected in their international competitiveness, was also highlighted by, among others, Falkowski (2017a, 2017c), Poghosyan (2017), Simsek et al. (2017), Udaltsova and Mikhelashvili (2016), Eletskikh (2015).

Despite the existing economic research on the competitiveness of the EAEU countries in international trade, there are no such studies which would attempt to determine the impact of Russia on the competitiveness of other EAEU countries and, what is more, to refer in this respect to trade in the high-tech goods category. Therefore, the importance of this article, which is intended to fill the identified gap in the international literature, is significant.

\section{Research methodology and data}

For the purposes of this article, the competitiveness of the economy in international trade is defined, as stated by Carbaugh (2017), as the ability to develop, manufacture and sell goods and services, more attractive in terms of price or quality than the export offer of other countries, as measured by the growing share of the international trade of the country in the sale of these goods to other countries. In addition to the above definition, it is important to stress the dynamic nature of this competitiveness, which is in fact the ability to benefit more rapidly (than other countries) from their own and foreign factors of production in an open economy (Weresa, 2014).

To determine the influence of Russia on the international competitiveness of Armenia, Belarus, Kazakhstan and Kyrgyzstan in the trade of high-tech goods, the original author's formula was used, which is a modification of the traditional method of analysis of the revealed comparative advantages of B. Balassa $(1965,1989)$, in which a hypothetical situation of a complete exclusion of exports of a particular country to another country (whose impact on the competitiveness of a given country we are examining) was taken into account, in the following form:

$$
R C A_{i j K \backslash r}^{K}=\ln \left(\frac{x_{i j}^{K}}{X_{j}^{K}} / \frac{x_{i j}^{K}-x_{i j \backslash r}^{K}}{X_{j}^{K}-X_{j \backslash r}^{K}}\right)
$$

where:

$R C A_{i j K \backslash r}^{K}$ - index of revealed comparative advantages of country $K$ in respect of $i$ goods category with the assumption of lack of exports of the $i$ goods category from country $K$ to country $r$, where $r \in j$

$x_{i j}^{K}$ - exports of $i$ goods category from country $K$ to country $j$, or group of countries $j$

$X_{j}^{K}$ - total exports from country $K$ to country $j$, or group of countries $j$

$x_{i j \backslash r^{\prime}}^{K}$ exports of $i$ goods category from country $K$ to country $j$, or group of countries $j$ with the assumption of lack of exports of the $i$ goods category from country $K$ to country $r$, where $r \in j$ $X_{j \backslash r}^{K}$ - total exports from country $K$ to country $j$, or group of countries $j$, with the assumption of lack of exports of the $i$ goods category from country $K$ to country $r$, where $r \in j$

$i$ - goods category

$K$ - analysed country 
$r$ - country or group of countries, for which an assumption of lack of exports from country $K$ was made, where $r \in j$

$j$ - the rest of the world

The proposed formula makes it possible to determine whether a given country $K$ has a revealed comparative advantage in terms of exports of $i$ goods category and in relation to a hypothetical situation where a given group of goods is not exported from country $K$ to country $r$ or a group of countries $r$. Thus, it is possible to assess whether the fact of exporting a specific $i$ goods category and from country $K$ to a specific country $r$ or a group of countries $r$ has a positive or negative impact (and how strong this impact is) on the actual comparative advantages of a given country $K$ in terms of a specific $i$ goods category in international trade.

The application of the complex form of the above formula allows to maintain the symmetry of positive and negative values of the index $R C A_{i j K \backslash r}^{K}$ in the range oscillating around zero, which facilitates its interpretation. If the value of $R C A_{i j K \backslash r}^{K}>0$ this means that the fact of exporting a particular $i$ goods category and country $K$ to a country or group of countries $\mathrm{r}$ improves the overall level of competitiveness of country $K$ in the trade of a given $i$ goods category and. On the other hand, if $R C A_{i j K \backslash r}^{K}<0$ then an improvement in the overall level of competitiveness of country $K$ in the trade of a given $i$ goods category occurs and if country $K$ does not export a given $i$ goods category at all from and to the country or group of countries in question.

This analysis was carried out in the period 2000-2016 for one of the 4 basic categories of goods according to the OECD classification based on their technological advancement, i.e. the high-tech goods category, in which the OECD includes the following subcategories: Aircraft and space; Pharmaceuticals; Office machinery and computers; Radio, television and telecommunications equipment and apparatus; Medical, precision and optical instruments; and Clocks and watches (Hatzichronoglou, 1997; Organisation for Economic Cooperation and Development, 2011).

All the necessary data used for the analysis are derived from the United Nations Commodity Trade Statistics Database.

\section{Empirical research results}

Before analysing the impact of Russia on the competitiveness of Armenia, Belarus, Kazakhstan and Kyrgyzstan in the international trade of high-tech goods, it is worth it to show the importance of Russia in the exports of these countries in general and in the high-tech goods category.

Taking into account Russia's share in total exports of other EAEU member countries, it should be clearly emphasized that it is traditionally the largest in Belarus and relatively the smallest in Kazakhstan (see Figure 1). The average share of Russia in total exports of these countries for the years 2000-2016 was $39.1 \%$ and $8.9 \%$, respectively. The corresponding figures for Armenia and Kyrgyzstan were $17.1 \%$ and $14.9 \%$, respectively.

The greatest fluctuations in the share of Russia in the Belarusian economy over the analysed period 2000-2016 are also clearly visible (see Figure 1). The record share in this respect was $53.2 \%$ in 2001, compared to only $31.5 \%$ in 2009 (down by 21.7 percentage points). One important reason for this was, of course, the negative consequences of the global economic crisis of 2008, which severely affected both the Belarusian and the Russian economies. After 2009, Russia's share in total exports increased systematically, albeit not uniformly, to reach a level of $46.3 \%$ in 2016.

On the other hand, in the case of Kazakhstan, it is worth noting that the significance of Russia as a market for goods has systematically reduced. While in 2000 Russia's share in total Kazakh exports was $19.7 \%$, in 2010 it was only $5.3 \%$ (down by as much as 14.4 percentage points). This was a result of the diversification of the geographical structure of foreign trade in Kazakhstan, i.a. due to the rise of China's importance in its foreign trade. After 2010, Russia's share in Kazakh exports increased, but only slightly, to reach a level of $9.5 \%$ in 2016 (i.e. the lowest among the other EAEU countries). In the case of Armenia and Kyrgyzstan, Russia's importance in total exports of these countries has been relatively stable over the analysis period, albeit also subject to some minor fluctuations. 


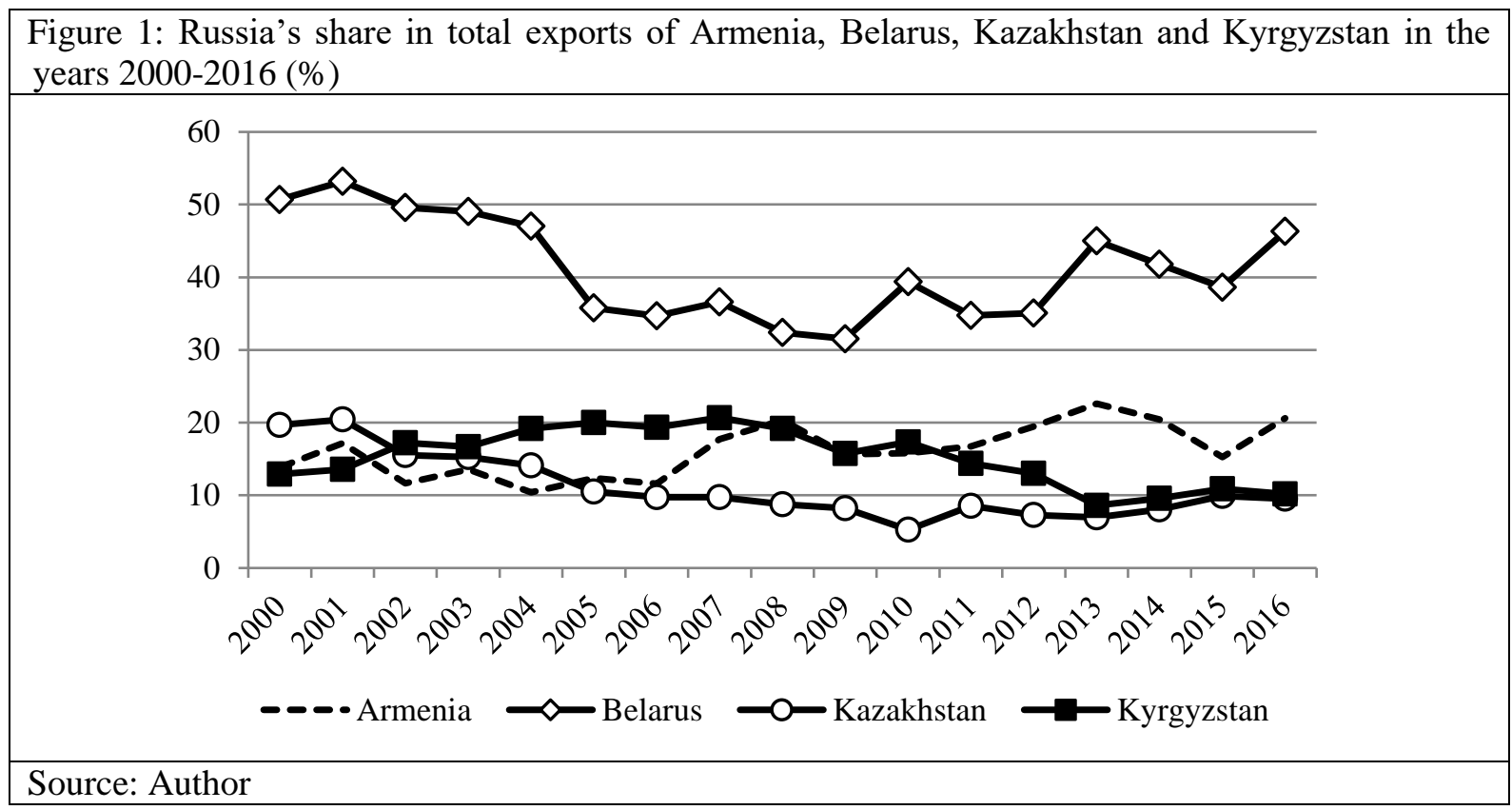

Analysing the data on Russia's significance in the exports of high-tech goods from the other EAEU countries (see Figure 2), what should be stressed, as before, is its biggest, and growing over the years 2000-2016, significance for the Belarusian economy. What is more, the average share of Russia in Belarusian high-tech exports in the analysed period was much higher than the average share of this country in total Belarusian exports, on average by as much as 22.8 percentage points. It ranged from $46.8 \%$ in 2005 to as much as $70.8 \%$ in 2013 (in 2016, it amounted to 69.3\%).

In the case of other EAEU countries, the significance of Russia in the exports of high-tech goods was subject to considerable fluctuations in the analysed period 2000-2016; however, it was significantly lower than in the case of Belarus. Suffice it to say that in the case of Kyrgyzstan it ranged from 1.8\% in 2015 to $61.3 \%$ in 2013, in the case of Kazakhstan from $6.1 \%$ in 2007 to $70.8 \%$ in 2012, and in the case of Armenia from $4.1 \%$ in 2012 to $45.1 \%$ in 2011.

However, it is difficult to say that there is a trend in this respect in these countries. Due to the relatively low value of high-tech goods exports, often individual sales transactions of this type to Russia have a very significant impact on the statistics, thus "doubling" the significance of Russia in this respect.

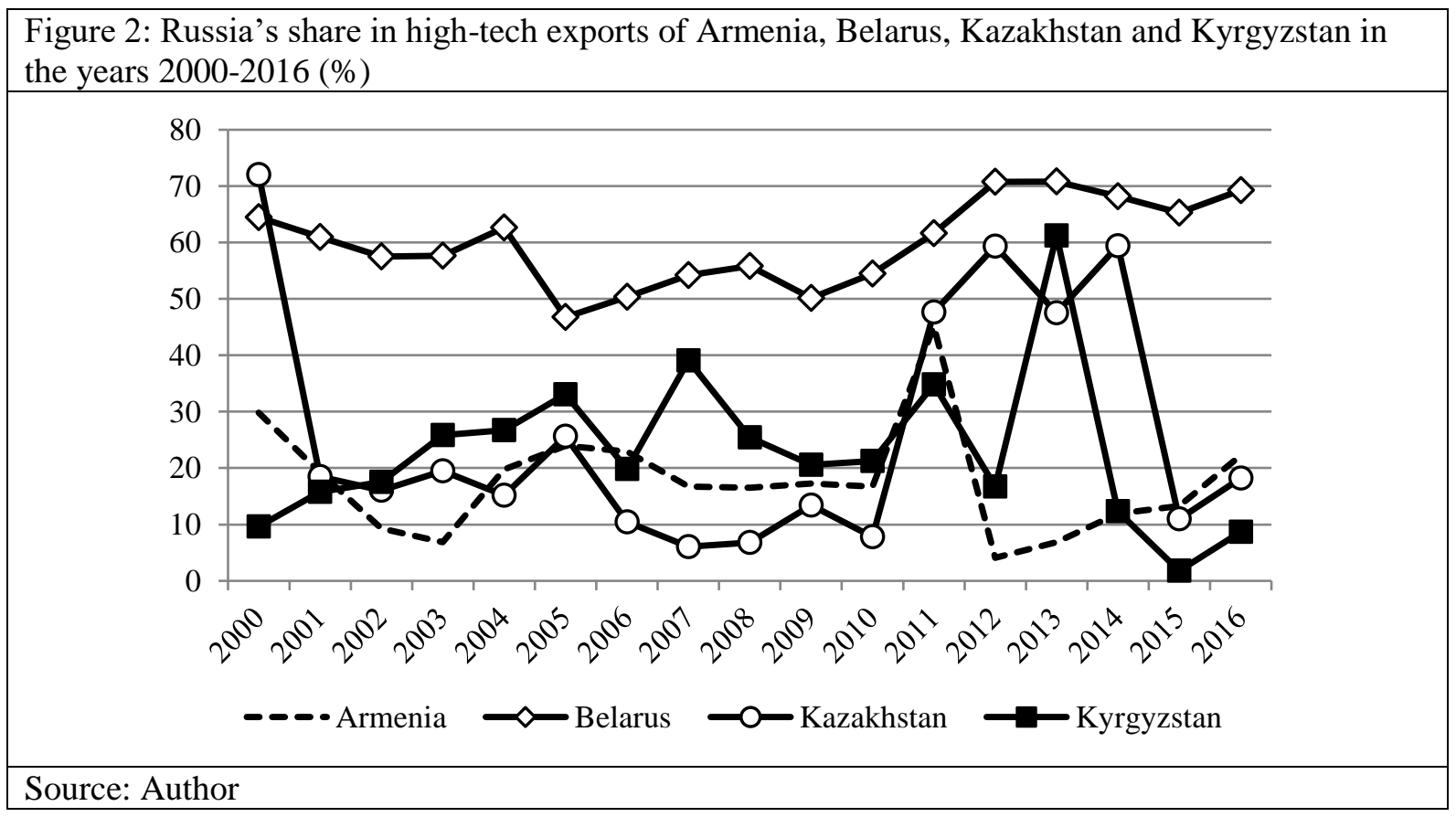


Turning to the analysis of Russia's impact (in terms of their exports to Russia) on the competitiveness of high-tech exports of Armenia, Belarus, Kazakhstan and Kyrgyzstan in the years 2000-2016, which is crucial from the point of view of this article, according to the methodology applied, it should be clearly emphasized that this impact was generally positive (the values of $R C A_{i j K \backslash r}^{K}>0$ ), although relatively diversified in terms of strength of that influence (see Figure 3).

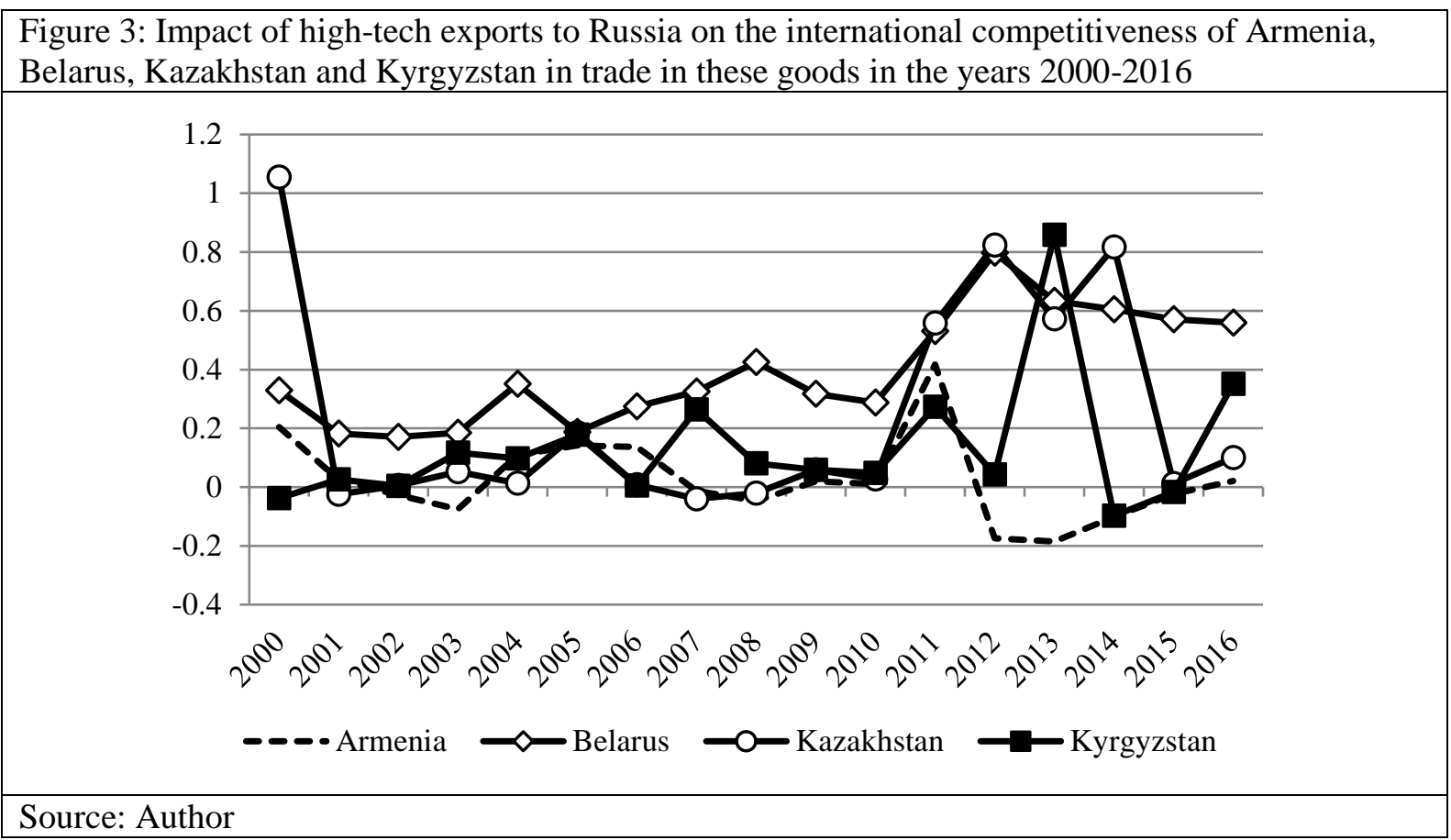

Throughout the period considered (with very few exceptions), Russia played the biggest positive role in the development of competitiveness of other EAEU member states in international high-tech trade, and specifically in the revealed comparative advantages in this respect, for Belarus. Had it not been for the export of Belarusian high-tech goods to Russia, their overall international competitiveness would have been even weaker. Thus, it turns out that Belarusian high-tech goods are sold on the Russian market, being relatively competitive there, which cannot be said about their presence on other foreign markets (including the EU), hence the crucial importance of Russia for the Belarusian economy in this respect. The possibility of exporting goods to the Russian market had by far the strongest positive impact on the competitiveness of Belarusian exports of goods from the Radio, TV and communications equipment subcategory, especially office machines and computers, as well as from the Medical, precision and optical instruments subcategory.

Russia has a positive influence on the development of international competitiveness of exports of high-tech goods also in the case of Kazakhstan and Kyrgyzstan. In the analysed period 2000-2016, it was lower than in the case of Belarus, but nevertheless it was observed for most of the years of this period. In the case of Kazakhstan, exports to Russia strengthened the competitiveness of the Radio, TV and communications equipment, Aircraft and spacecraft, as well as Medical, precision and optical instruments subcategories; and for Kyrgyzstan and Armenia - in the Medical, precision and optical instruments subcategory.

Referring to Armenia, it should be noted that in this case the positive impact of Russia on the competitiveness of its high-tech exports was relatively the lowest among all the EAEU countries. Moreover, in total, this impact was even negative for slightly more than half of the period considered.

At the end of the analysis of Russia's influence (in terms of their exports to Russia) on the development of international competitiveness of Armenia, Belarus, Kazakhstan and Kyrgyzstan in the trade of high-tech goods, it is worth noting the real effects of this influence manifested in the actual competitive position of these countries in international trade. For this purpose, the logarithmical original formula of the method of analysing revealed comparative advantages in foreign trade by B. Balassa was used $(1965,1989)$. 


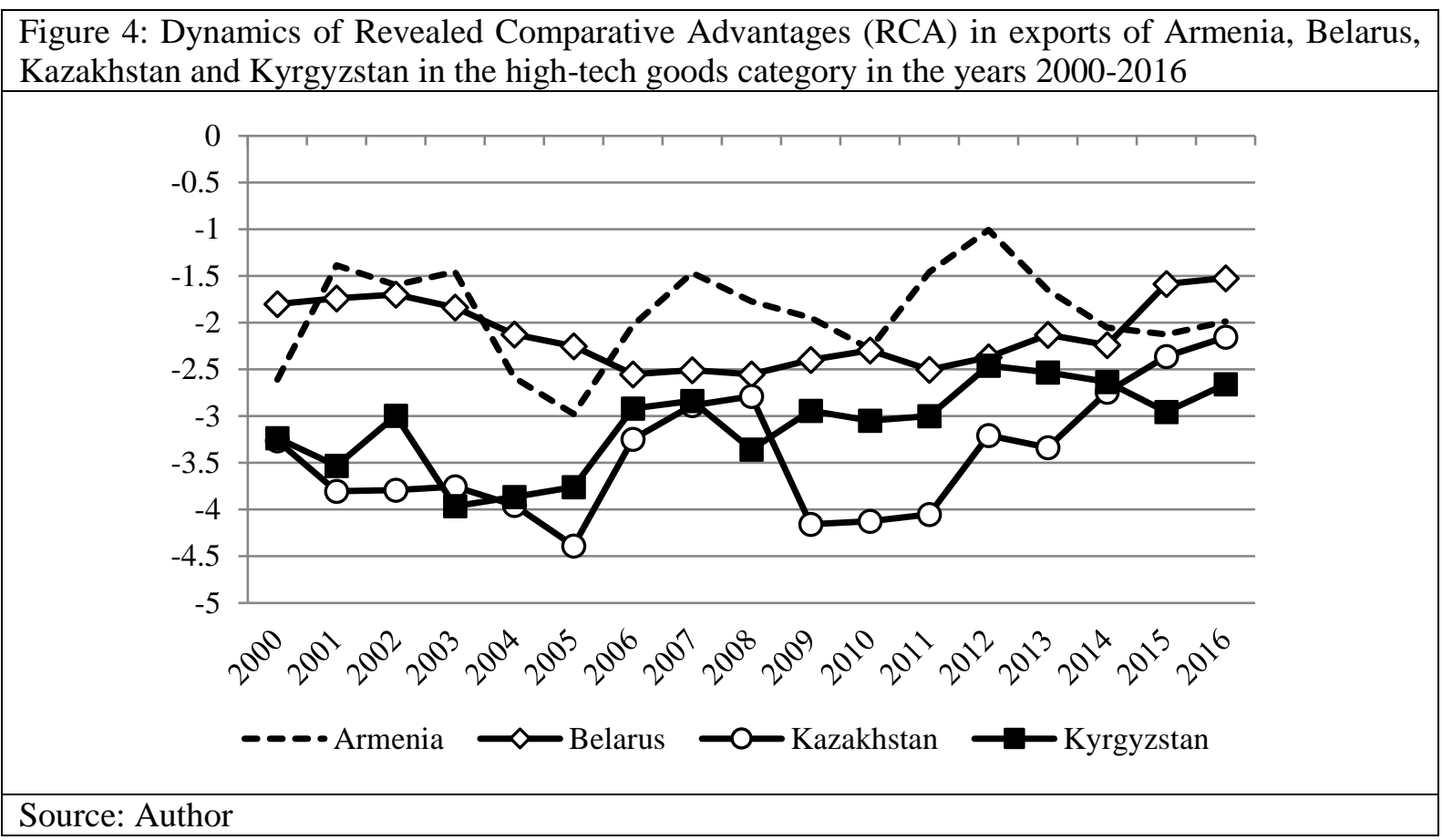

As shown in Figure 4, all the other EAEU countries without exception are completely uncompetitive in the international trade of high-tech goods. Moreover, it was also difficult to see any significant improvement over the period 2000-2016. It turns out, therefore, that despite the positive influence of Russia (in terms of their exports to Russia) on the level of competitiveness of these countries' exports of high-tech goods, their overall real competitiveness remained practically at a similar level, reflecting their uncompetitive position on the international arena, which was exemplified by the lack of comparative advantages in trade in this goods category throughout the analysed period 2000-2016 (see Figure 4). Therefore, the existence of the Eurasian Economic Union and the thus facilitated access of member states to the large Russian market, from the point of view of their general (international) competitiveness in the trade of high-tech goods, was not able to ensure that they achieved real comparative advantages on the international arena.

\section{Conclusions}

The subject of this article was the analysis of the influence of Russia (in terms of their exports to Russia) on the competitiveness of Armenia, Belarus, Kazakhstan and Kyrgyzstan in the international trade of high-tech goods in the years 2000-2016 in the context of their general competitiveness in the international trade of this goods category.

The analysis of the issue shows that Russia's influence (in terms of their exports to Russia) on the international competitiveness of Armenia, Belarus, Kazakhstan and Kyrgyzstan in the area of hightech goods trade in 2000-2016 was generally positive. This means that if these countries had not exported their high-tech goods to Russia, their international trade competitiveness in this area would have been much worse than it is in the situation of the existence of such exports to Russia. This confirms the view of low competitiveness of these goods, which without the possibility of selling them on the Russian market within the framework of the Eurasian Economic Union would be even more uncompetitive on the international arena. The very low competitiveness of high-tech goods from Armenia, Belarus, Kazakhstan and Kyrgyzstan is evidenced by the fact that none of these countries has any revealed comparative advantages in the export of this goods category on a global scale.

Can this state be changed? It is undoubtedly worth trying, given the realities of the modern world and the growing role of knowledge, technology, innovation and, therefore, high-tech goods in international trade. This will be an extremely ambitious task for these countries, as it will undoubtedly be extremely difficult to produce goods that are able to compete outside the markets in the wider post-Soviet area, including, above all, the Russian market.

In order to improve the competitive position of Armenia, Belarus, Kazakhstan and Kyrgyzstan in the international trade of high-tech goods, it is absolutely necessary for the authorities of these countries to 
take effective measures to improve the institutional environment, and the determining conditions for doing business in these countries in order to attract technologically advanced foreign capital investments, which would consequently make it possible to launch spillover effects and improve the innovativeness of their economies, which in turn could translate into the acquisition of certain comparative advantages in the area of trade in high-tech goods. Secondly, it also seems necessary to consistently implement pragmatically formulated innovation policies in these countries, aimed at increasing the effectiveness of cooperation between state institutions, universities and research centres, as well as enterprises for the purpose of creating and commercialising high-tech product solutions. Undoubtedly, this cannot be achieved without a greater "integration" of these economies into international economic cooperation, which must also be associated with the need to successfully complete the systemic institutional transformation in these countries, including, inter alia, the implementation of structural economic reforms towards knowledge-based market economies.

\section{References}

Balassa, B. (1965). Trade liberalization and 'revealed' comparative advantage. The Manchester School of Economic and Social Studies, 33.

Balassa, B. (1989). 'Revealed' comparative advantage revisited. In B. Balassa (Ed.), Comparative advantage, trade policy and economic development. New York: New York University Press.

Carbaugh, R. (2017). International Economics. Boston: Cengage.

Eletskikh, G. (2015). Development of innovative systems: problems and prospects of today's Russia. Russian Journal of Innovation Economics, 5(4), 159-172.

Falkowski, K. (2017a). Innovativeness of Belarusian economy through the prism of its competitive position in international trade. CBU International Conference Proceedings, 5, 120-127.

Falkowski, K., (2017b). Long-Term Comparative Advantages of the Eurasian Economic Union Member States in International Trade. International Journal of Management and Economics, 53(4), 27-49.

Falkowski, K. (2017c). The resources-dependent competitive profile of Kazakhstan and its consequences for the country's future development. Prace Naukowe Uniwersytetu Ekonomicznego we Wrocławiu, 486, 92-102.

Hartwell, Ch. A. (2016). Improving competitiveness in the member states of the Eurasian Economic Union: a blueprint for the next decade. Post-Communist Economies, 28(1), 49-71.

Hatzichronoglou, T. (1997). Revision of the high technology sector and product classification. STI Working Papers 1997/2. OECD/GD 97(216). Paris: Organisation for Economic Co-operation and Development.

Knobel, A. (2017). The Eurasian Economic Union: Development Prospects and Possible Obstacles. Problems of Economic Transition, 59(5), 335-360.

Organisation for Economic Co-operation and Development. (2011). ISIC Rev. 3 Technology intensity definition. Classification of manufacturing industries into categories based on $R \& D$ intensities. Retrieved March 06, 2018, from http://www.oecd.org/sti/ind/48350231.pdf.

Poghosyan, T. (2017). The State of the National Innovation System of Armenia. In A. Tsvetkova, J. Schmutzler, M. Suarez, \& A. Faggian (Eds.), Innovation in Developing and Transition Countries, Cheltenham: Edward Elgar Publishing.

Simsek, N., Simsek, H. A., \& Nurbayev, D. (2017). Kazakhstan's Competitiveness in the Eurasian Economic Union Market. Sosyoekonomi, 25(3), 81-102.

Udaltsova, N., \& Mikhelashvili, N. (2016). Competitiveness of the national innovation system in Russia: an analytical review. Creative Economy, 10(1), 9-20.

Ustyuzhanina, E. (2016). The Eurasian Union and the global value chains. European Politics and Society, 17, 35-45.

Vinokurov, E. (2017). Eurasian Economic Union: current state and preliminary results. Russian Journal of Economics, 3(1), 54-70.

Weresa, M. A. (Ed.). (2014). Innovation, Human Capital and Trade Competitiveness. How Are They Connected and Why Do They Matter?. Switzerland: Springer International Publishing. 